\title{
ASOSIASI ULIN (Eusideroxylon zwageri Teijsm et Binn) TERHADAP JENIS DOMINAN PADA ZONA DOMESTIKA KEBUN RAYA SAMBAS KABUPATEN SAMBAS
}

\author{
Association Of Ulin (Eusideroxylon Zwageri Teijsm Et Binn) Towards Dominant Types In \\ Domestic Zone Of Sambas Botanical Garden Sambas District
}

\author{
Dhanu Arya Prayoga, Iswan Dewantara, Ratna Herawatinigsih \\ Fakultas Kehutanan Universitas Tanjungpura, Jalan Imam Bonjol Pontianak 78124 \\ Email: dhanunarukami@gmail.com
}

\begin{abstract}
Ulin or Belian or Ironwood with the scientific name Eusideroxylon zwageri Teijsm et Binn is a vegetation of Borneo endemic trees. Along with utilization to meet the needs of community boards and traded in an uncontrolled manner this tree is endangered. Due to the absence of a truly good cultivation business of intansi, the government, and the community, ironwood is threatened by its existence. The research aims to get the Ulin Association (Eusideroxylon zwageri Teijsm et Bin) against species that dominate in the Sambas Botanical Garden Domestic Zone, Sambas Regency. The study was conducted from 02-23 September. This research uses survey method. The research sample was taken by using a single square quadratic method by determining the area of the Observation Sample Plot Area (PCP) by purposive sampling with 25 sub plots per plot. The result has no real reciprocal relationship or association. But it shows the tolerance to live together in one area. Red Meranti is the most dominant species, especially Shorea pinanga is a species that dominates in the domestic zone with INP trees (59.3760), poles (58.2746), saplings (53.5636), seedlings (55.5699). Pole level Shorea pinanga has a strong association with the Eusideroxylon zwageri T et B plant (7.02), but has a very low association index (0.1428).
\end{abstract}

Keyword: ulin, association, dominant

\section{PENDAHULUAN}

Ulin, Belian, Kayu besi dengan nama ilmiah Eusideroxylon zwageri Teijsm et Binn merupakan vegetasi pohon endemik Kalimantan. Seiring pemanfaatan untuk memenuhi kebutuhan papan masyarakat dan diperdagangkan secara tidak terkendali menyebabkan pohon ini terancam punah. Karena tidak adanya usaha budidaya yang sungguh-sungguh baik intansi, pemerintah, dan masyarakat sehingga tumbuhan ulin terancam keberadaannya (Riskan, 2009).

Pemanfaatan kayu Ulin sudah dilakukan oleh suku Dayak di pulau Kalimantan sejak lama, sehingga banyak nilai budaya dari kayu Ulin tersebut. Banyaknya keberagaman pemanfaatan kayu ulin seperti di uraikan terdahulu menunjukan bahwa masyarakat suku Dayak sangat membutuhkan jenis kayu Ulin tersebut dikarenakan kelasnya yang kuat (Sastrapradja et al, 1977 dalam Hidayat, 2003).

Tanaman ulin memiliki manfaat ekologi, pohon ulin ini merupakan tempat tinggal orangutan, dan daun muda dari pohon ulin ini dapat dimanfaatkan sebagai makanan orang hutan. Ulin juga mampu menghasilkan manfaat oksigen dan menyerap karbondioksida di siang hari yang disebut fotosintesis. Ulin juga mampu mempertahankan manfaat air tanah, menahan air dan tanah itu sendiri sehingga mencegah tanah dari erosi dan longsor. 
Manfaat pohon Ulin ini sangat banyak sehingga menjadi incaran manusia, dan populasinya lama kelamaan menurun dan kepunahannya jelas dan nyata. Ini dikarenakan eksplorasi kayu Ulin secara besarbesaran di masa lampau, sehingga populasinya menurun drastis (Noorhidayah et al, 2006). Ditambah lagi pertumbuhan ulin yang sangat lambat sehingga jarang masyarakat ataupun investor yang mau mengembangkan pohon ini (Sidiyasa, 1995 dalam Kade Sidiyasa et al, 2013).

Domestika adalah suatu daerah yang mana di dalamnya terdapat suatu populasi tumbuhan atau hewan yang menempati suatu tempat kemudian menjadi bagian dari tempat tersebut (Kilian et al, 2000). Dalam suatu komunitas tumbuhan hutan terjadi interaksi antara spesies anggota populasi (Indriyanto, 2006). Ada spesies yang harus menumpang hidup pada tumbuhan lain, ada pula yang membutuhkan naungan dari tumbuhan lain untuk hidup, sehingga mereka dapat tumbuh berdampingan membentuk sebuah komunitas hutan.

Menurut Kurniawan et al (2008) hubungan ketertarikan untuk tumbuh bersama ini dikenal dengan asosiasi yang dapat bersifat positif maupun negatif atau tidak berasosiasi. Informasi mengenai asosiasi ini sangat penting sebagai bahan pertimbangan dalam upaya untuk mengoptimalkan budidaya jenis ulin. Oleh karena itu, penelitian ini bertujuan untuk mengetahui asosiasi jenis ulin dengan pohon-pohon dominan di kawasan Kebun Raya Sambas.

Tujuan penelitian ini adalah untuk mendapatkan Asosiasi Ulin (Eusideroxylon zwageri Teijsm et Bin) terhadap spesies yang mendominasi
Pada Zona Domestika Kebun Raya Sambas, Kabupaten Sambas.

METODE PENELITIAN

Penelitian ini dilakukan di Kebun Raya Sambas Kabupaten Sambas Kecamatan Subah.mulai tanggal 2 September s/d 23 September 2019. Penelitian menggunakan metode survey. Pengambilan sampel penelitian menggunakan metode kuadrat petak tunggal dengan penentuan area lokasi Petak Contoh Pengamatan (PCP) 100x100 (m) secara purposive sampling dengan 25 sub petak setiap petaknya. Setiap petak berukuran 20x20 (m) untuk pohon, 10x10 (m) untuk tiang, 5x5 (m) untuk pancang, dan $2 \times 2$ (m) untuk semai.

Teknik pengumpulan data dilakukan dengan mendata semua jenis tumbuhan pada zona domestik dimulai dari tingkat semai, pancang, tiang, dan pohon melalui petak contoh pengamatan (PCP) dengan luas 100x100 (m) dengan $25 \mathrm{sub}$ petak. Kemudian dilanjutkan dengan identifikasi setiap tumbuhan yang telah ditemukan pada zona domestik.

Pengolahan data pertama dilakukan dengan perhitungan indeks nilai penting (INP) untuk mengetahui tumbuhan mana yang dominan pada zona domestik. Berikut rumus untuk menentukan indeks nilai penting (INP) menurut (MuellerDombois dan Ellenberg ,1974 dalam Agung et al, 2014).

1. Kerapatan $(\mathrm{K})=\frac{\text { Jumlah Individu setiap spesies }}{\text { Luas Petak Ukur }}$ $\mathrm{KR}=\frac{\text { Kerapatan suatu jenis }}{\text { Kerapatan seluruh jenis }} \times 100 \%$

2. Frekuensi $(F)=\frac{\text { Jumlah petak suatu jenis }}{\text { Jumlah petak seluruh jenis }}$ $\mathrm{FR}=\frac{\text { Frekuensi suatu jenis }}{\text { Frekuensi seluruh jenis }} \times 100 \%$

3. Dominansi (D) $=\frac{\text { Jumlah luas bidang datar suatu jenis }}{\text { luas petak ukur }}$ $=\frac{\text { luas petak ukur }}{\text { Dominansisuatu }}$ $\mathrm{DR}=\frac{\text { Dominansi suatu jenis }}{\text { Dominansi seluruh jenis }} \times 100 \%$

4. (INP) tingkat Semai dan pancang $=\mathrm{KR}+$ FR

5. (INP) tingkat tiang dan Pohon $=\mathrm{KR}+\mathrm{FR}+$ DR 
Keterangan :

FR = Frekuensi Relatif

$\mathrm{KR}=$ Kerapatan Relatif

$\mathrm{DR}=$ Dominasi Relatif

INP = Indeks Nilai Penting
Kemudian dilanjutkan dengan menghitung Asosiasi dan Tingkatan Kekuatan Asosiasi menggunakan tabel kontingensi 2x2 (Kurniawan et al, 2008) dengan rumus berikut :

Tabel 1. Tabel Kontingensi 2x2 Untuk Mengukur Hubungan Antara Dua Tumbuhan (Contingency Table to Measure The Association Between Two Plants)

\begin{tabular}{ccccc}
\hline POHON & PCP & \multicolumn{3}{c}{ JENIS B (POHON ULIN) } \\
\cline { 2 - 5 } DOMINAN & & Ada & Tidak Ada & Jumlah \\
\hline \multirow{3}{*}{ JENIS A } & Ada & a & b & $\mathbf{a}+\mathbf{b}$ \\
\cline { 2 - 5 } & Tidak Ada & c & d & $\mathbf{c}+\mathbf{d}$ \\
\cline { 2 - 5 } & Jumlah & $\mathbf{a}+\mathbf{c}$ & $\mathbf{b}+\mathbf{d}$ & $\mathbf{N}=\mathbf{a}+\mathbf{b}+\mathbf{c}+\mathbf{d}$
\end{tabular}

Keterangan :

a : Jumlah PCP yang ada spesies A dan spesies B (Pohon Ulin)

b : Jumlah PCP yang ada spesies A (Pohon Dominan)

c : Jumlah PCP yang ada spesies B (Pohon Ulin)

d : Jumlah PCP yang tidak ada spesies A dan spesies B

$\mathrm{N}$ : Jumlah PCP (Petak Contoh Pengamatan)

Kemudia dilanjutkan dengan

membandingkan Nilai Chi-square hitung dengan nilai Chi-square tabel pada derajat bebas $=1$, pada uji taraf $1 \%$ dan 5\% (nilai 3,84). Apabila nilai Chisquare hitung > nilai Chi-square tabel, maka asosiasi bersifat nyata dan sebaliknya (Ludwig dan Reynold, 1975 dalam Djoko, 2012). Selanjutnya untuk mengetahui tingkat atau kekuatan asosiasi digunakan rumus sebagai berikut :

Nilai Chi-square hitung kemudian dibandingkan dengan nilai Chi-square tabel pada derajat bebas $=1$, pada uji taraf $1 \%$ dan 5\% (nilai 3,84). Apabila nilai Chi-square hitung > nilai Chisquare tabel, maka asosiasi bersifat nyata dan sebaliknya (Ludwig dan Reynold, 1975 dalam Djoko, 2012). Selanjutnya untuk mengetahui tingkat atau kekuatan asosiasi digunakan rumus sebagai berikut :

$$
\mathrm{E}(\mathrm{a})=\frac{(a+b)(a+c)}{N}
$$

Keterangan :

a : Jumlah PCP yang ada spesies A dan spesies B ada

b : Jumlah PCP yang ada spesies A ada, dan jenis B tidak ada

c : Jumlah PCP yang ada spesies B ada, dan jenis A tida ada

d : Jumlah PCP yang tidak ada spesies A dan spesies B

N : Total PCP (Petak Contoh Pengamatan)

Berdasarkan rumus tersebut, maka terdapat 2 jenis asosiasi yaitu (1) asosiasi positif, apabila a $>E(a)$ berarti pasangan jenis terjadi bersama lebih dari yang diharapkan. (2) asosiasi negatif, apabila nilai a $<\mathrm{E}(\mathrm{a})$ berarti pasangan jenis terjadi bersama kurang sering dari yang diharapkan. Ukuran asosiasi yang diperoleh dengan rumus Indeks Jaccard (Ludwig dan Reynolds, 1998) dalam Dewantara (2017) sebagai berikut:

Indeks Jaccard $(\mathrm{Ji})=\frac{a}{a+b+c}$

Keterangan : 
a : Jumlah PCP ditemukannya kedua jenis tanaman jenis $a$ dan $b$

b : Jumlah PCP ditemukannya jenis a tetapi jenis $b$ tidak ada

c : Jumlah PCP ditemukannya jenisb tetapi jenis a tidak ada

Selang nilai Indeks Jaccard adalah 0 - 1. Nilai 0 merupakan nilai minimum, yang menunjukkan tidak adanya asosiasi, sedangkan nilai 1 menunjukkan nilai maksimum yang menunjukkan tingkat asosiasi tinggi. Kategori Nilai Indeks Asosiasi sangat tinggi (ST) 0,75 - 1, tinggi (T) 0,49 - 0,74, rendah (R) $0,23-0,48$, dan sangat rendah (SR) $<0,22$ (Kurniawan et al, 2008).

\section{HASIL DAN PEMBAHASAN Dominansi Dan Indeks Nilai Penting Berbagai Jenis Tegakan di Tingkat Pohon}

Jenis-jenis pohon yang ditemukan 22 jenis dengan jumlah individu 198 pohon. Berdasarkan hasil perhitungan Indeks Nilai Penting (INP) dari 22 jenis pada tingkat pohon yang memenuhi kriteria sebagai pohon yang dominan penyusun tegakan di Kebun Raya Sambas (dengan kriteria nilai INP $\geq$ $15 \%$ ) ada 6 jenis, seperti yang tertera pada tabel berikut:

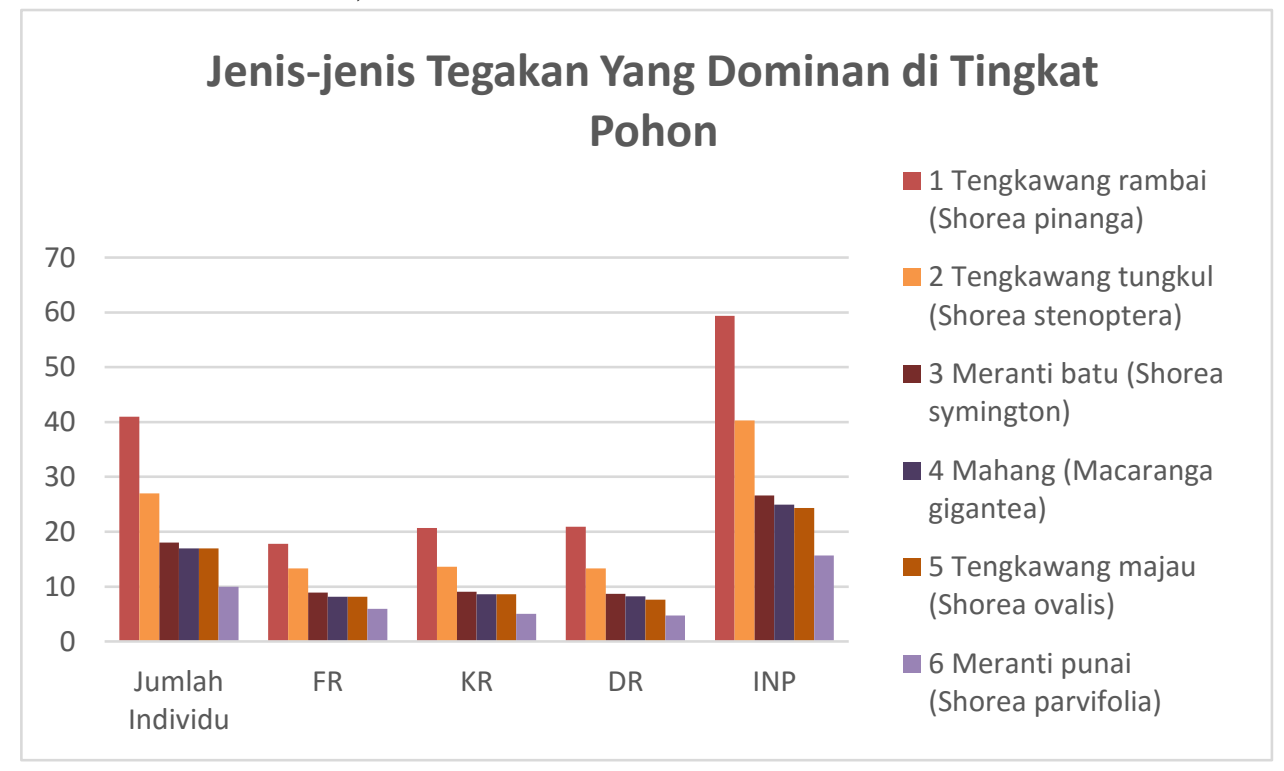

Gambar 1. Grafik Jenis-Jenis Pohon Yang Dominan Pada Tegakan Tingkat Pohon (Graphic of Dominant Tree Types at Tree Level Standards)

Berdasarkan data di atas dari 6 spesies yang mendominasi pada strata pohon mayoritas adalah famili Dipterocarpaceae yaitu Shorea pinanga, Shorea stenoptera, Shorea symington, Shorea ovalis, dan Shorea parvifolia. Sedangkan dari famili lain hanya 1 spesies yaitu Macaranga gigantea dari famili Euphorbiaceae. Salah satu contoh kondisi tegakan strata pohon dari famili Dipterocarpaceae yaitu spesies Shorea pinanga

Hasil ini menunjukkan bahwa dari 6 jenis yang mendominasi pada strata pohon tidak ditemukan ulin (Eusideroxylon zwageri $\mathrm{T}$ et $\mathrm{B}$ ). Kondisi 
ini dikarenakan sebelum adanya aturan tentang penebangan (Peraturan Daerah Provinsi Kalimantan Barat Nomor 8 Tahun 2006) Tentang Pemanfaatan dan Peredaran Kayu Ulin Dalam Wilayah Kalimantan Barat, banyak masyarakat yang menebang pohon ulin di Kebun Raya Sambas karena pada saat itu belum ada pengelolaannya, sehingga lama kelamaan pohon ulin pada areal tersebut terdegradasi. Untuk tingkat pohon di Kebun Raya Sambas pada Zona Domestika hanya di temukan 2 pohon ulin yang tersisa akibat penebangan liar.
Sehingga pohon ulin tidak menjadi pohon dominan pada zona Domestik.

Dominansi Dan Indeks Nilai Penting Berbagai Jenis Tegakan di Tingkat Tiang

Jenis-jenis tiang yang ditemukan sebanyak 20 jenis dengan jumlah individu 206 tiang. Berdasarkan hasil perhitungan Indeks Nilai Penting (INP) dari 20 jenis pada tingkat tiang yang memenuhi kriteria sebagai tiang yang dominan penyusun tegakan di Kebun Raya Sambas (dengan kriteria nilai INP $\geq 15 \%$ ) ada 8 jenis termasuk ulin, seperti tertera pada tabel berikut :

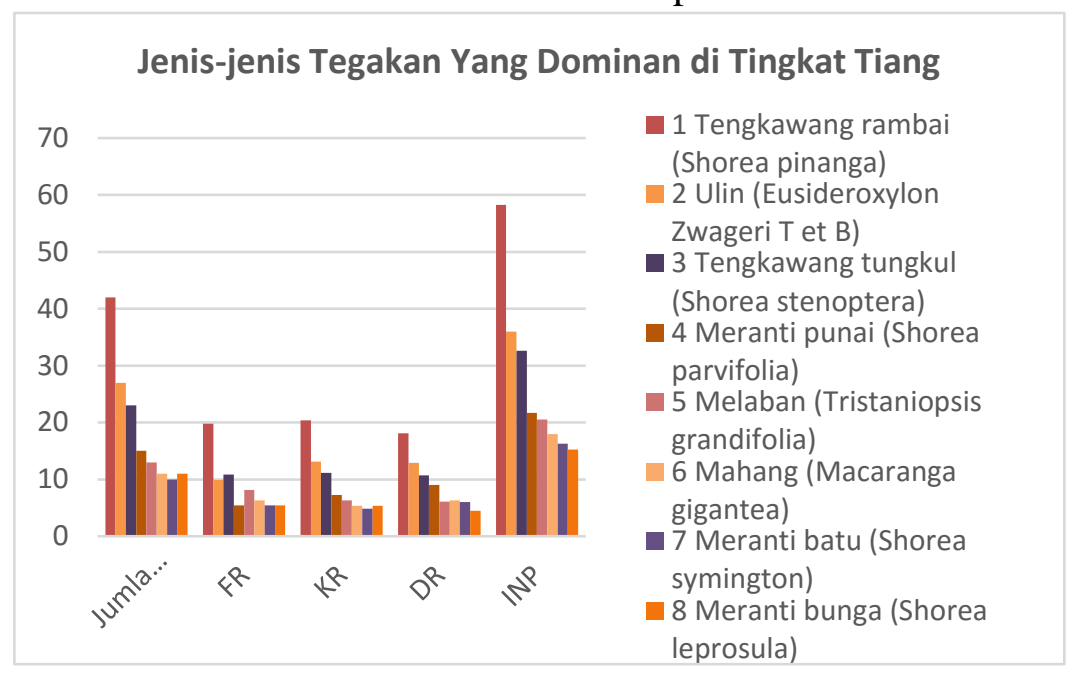

Gambar 2. Grafik Jenis-Jenis Tiang Yang Dominan Pada Tegakan Tingkat Tiang (Graphic Types of Dominant poles At Pole Level Standards)

Berdasarkan data di atas spesies yang mendominasi pada strata tiang mayoritas adalah famili Dipterocarpaceae yaitu Shorea pinanga, Shorea stenoptera, Shorea symington, Shorea leprosula, dan Shorea parvifolia. Sedangkan dari famili lain hanya 1 spesies yaitu Macaranga gigantea dari famili Euphorbiaceae dan Tristaniopsis grandifolia dari famili Myrtaceae . Dari 8 jenis yang tersebar pada tingkat tiang ditemukan jenis ulin (Eusideroxylon zwageri $\mathrm{T}$ et $\mathrm{B}$ ). Ini dikarenakan pada tingkat tiang merupakan hasil regenarasi ulin yang telah ditebang sebelum Kebun Raya Sambas dikelola. Banyaknya tingkat tiang pada Zona Domestika tersebut tidak lepas dari keadaan lingkungan seperti: topografi, banyaknya vegetasi, dan jenis tanah (Sidiyasa, 2011) yang mendukung 
pertumbuhan ulin sehingga proses regenerasinya pun berjalan baik.

\section{Dominansi Dan Indeks Nilai Penting Berbagai Jenis Tegakan di Tingkat Pancang}

Jenis-jenis pancang yang ditemukan sebagai penyusun tegakan di Kebun Raya Sambas, sebanyak 19 jenis dengan jumlah individu 567 pancang.
Berdasarkan hasil perhitungan Indeks Nilai Penting (INP) dari 19 jenis pada tingkat pancang yang memenuhi kriteria sebagai pancang yang dominan penyusun tegakan di Kebun Raya Sambas (dengan kriteria nilai INP $\geq$ $10 \%$ ) ada 7 jenis, seperti tertera pada tabel berikut:

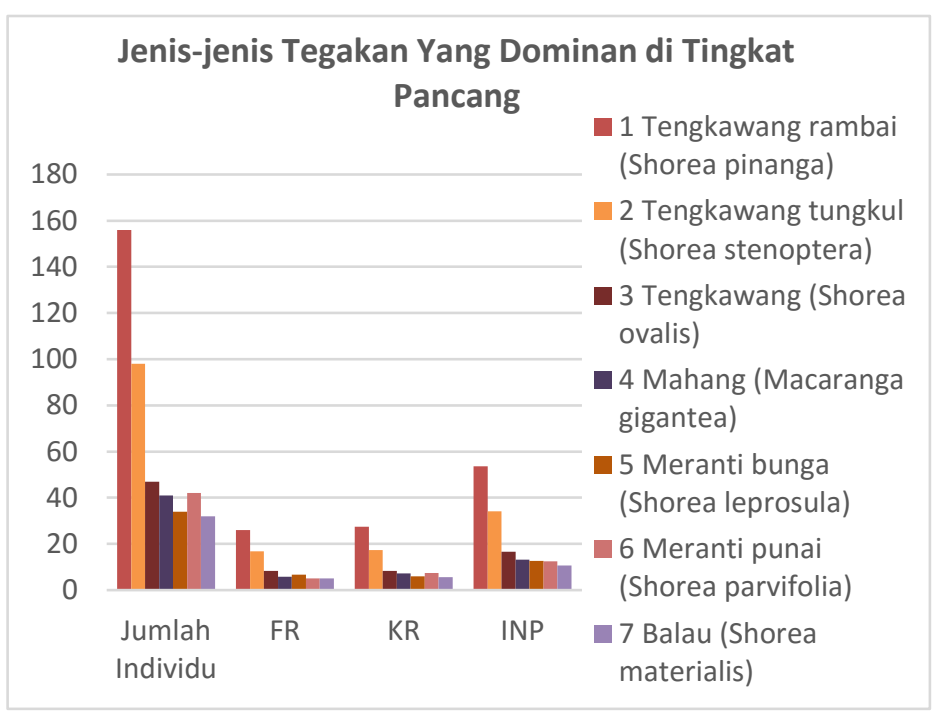

Gambar 3. Grafik Jenis-Jenis Pancang Yang Dominan Pada Tegakan Tingkat Pancang Graphic of Dominant Stakes Types at Stake Level Standards)

Berdasarkan data di atas dari 7 spesies yang mendominasi pada strata pancang mayoritas adalah famili Dipterocarpaceae yaitu Shorea pinanga, Shorea stenoptera, Shorea leprosula, Shorea ovalis, dan Shorea parvifolia. Sedangkan dari famili lain hanya 1 spesies yaitu Macaranga gigantea dari famili Euphorbiaceae. Dari 7 jenis yang tersebar pada tingkat pancang tidak ditemukan jenis ulin (Eusideroxylon zwageri $\mathrm{T}$ et $\mathrm{B}$ ). Ini dikarenakan sulitnya tingkat pancang untuk bersaing mendapatkan unsur hara pada Zona Domestika. Tumbuhan ulin termasuk tanaman yang semi-toleran terhadap matahari, ketika pada tingkat pancang dia membutuhkan sedikit cahaya. Namun karena vegetasi yang padat membuat ulin sulit untuk menerima cahaya matahari. Hanya ditemukan 3 ulin tingkat tiang yang ditemukan pada Zona Domestika Sehingga pancang ulin tidak menjadi pancang dominan pada zona Domestik.

\section{Dominansi Dan Indeks Nilai Penting Berbagai Jenis Tegakan di Tingkat Semai}

Jenis-jenis semai yang ditemukan sebanyak 17 jenis dengan jumlah individu 502 semai. Berdasarkan hasil perhitungan Indeks Nilai Penting (INP) 
dari 17 jenis pada tingkat semai yang memenuhi kriteria sebagai semai yang dominan penyusun tegakan di Kebun
Raya Sambas (dengan kriteria nilai INP $\geq 10 \%$ ) ada 4 jenis, seperti tertera pada Gambar berikut:

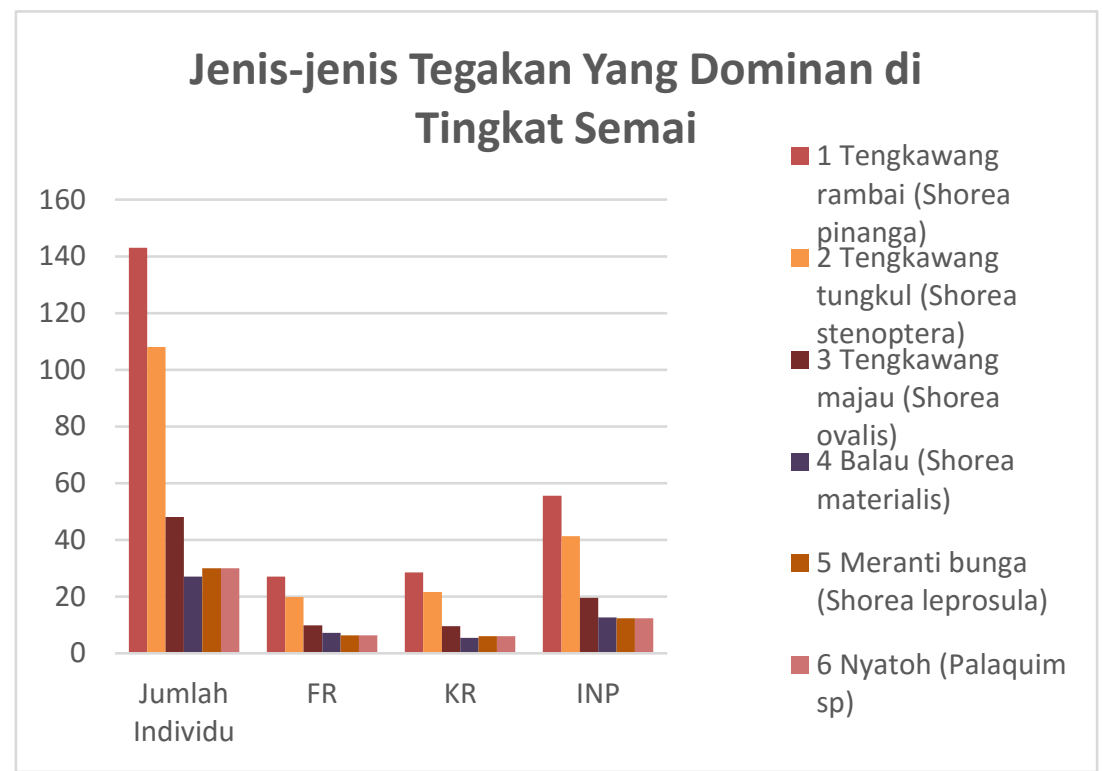

Gambar 4. Grafik Jenis-Jenis Semai Yang Dominan Pada Tingkat Tegakan Semai Graphic of Dominant Seeds Types at Seed Level Standards)

Berdasarkan data di atas dari 6 spesies yang mendominasi pada strata semai mayoritas adalah famili Dipterocarpaceae yaitu Shorea pinanga, Shorea stenoptera, Shorea symington, Shorea ovalis, dan Shorea parvifolia. Dari 6 jenis yang tersebar pada tingkat semai tidak ditemukan jenis ulin (Eusideroxylon zwageri $\mathrm{T}$ et $\mathrm{B}$ ). Ini dikarenakan belum adanya regenerasi ulin dari tingkat pohon, sehingga semai ulin tidak menjadi yang dominan pada Zona Domestik Kebun Raya Sambas, karena tidak ditemukan potensi pertumbuhan baik biji atau benih ulin pada areal tersebut. Sehingga tidak ada hitungan lanjutan untuk mencari Kontigensi asosiasi dan Kekuatan Asosiasi pada tingkat ini karena tidak ditemukan ulin.

\section{Kekuatan Asosiasi Ulin Dengan Tegakkan Yang Mendominasi}

Hasil perhitungan INP diperoleh 6 pohon dominan, 8 tiang dominan, 7 pancang dominan dan 6 semai dominan yang memiliki INP $\geq 15 \%$ (pohon dan tiang) dan INP $\geq 10 \%$ (pancang dan semai. Untuk tingkat semai tidak ditemukan tumbuhan Ulin yang berasosiasi dengan tanaman lain sehingga untuk tingkat semai tidak dilakukan hitungan lanjutan. Hasil uji kontigensi antara jenis ulin dengan tumbuhan dominan harus dilanjutkan dengan penghitungan kekuatan asosiasi agar dapat mengetahui kuat atau lemahnya tipe asosiasi. Hasilnya seperti pada tabel berikut : 
A

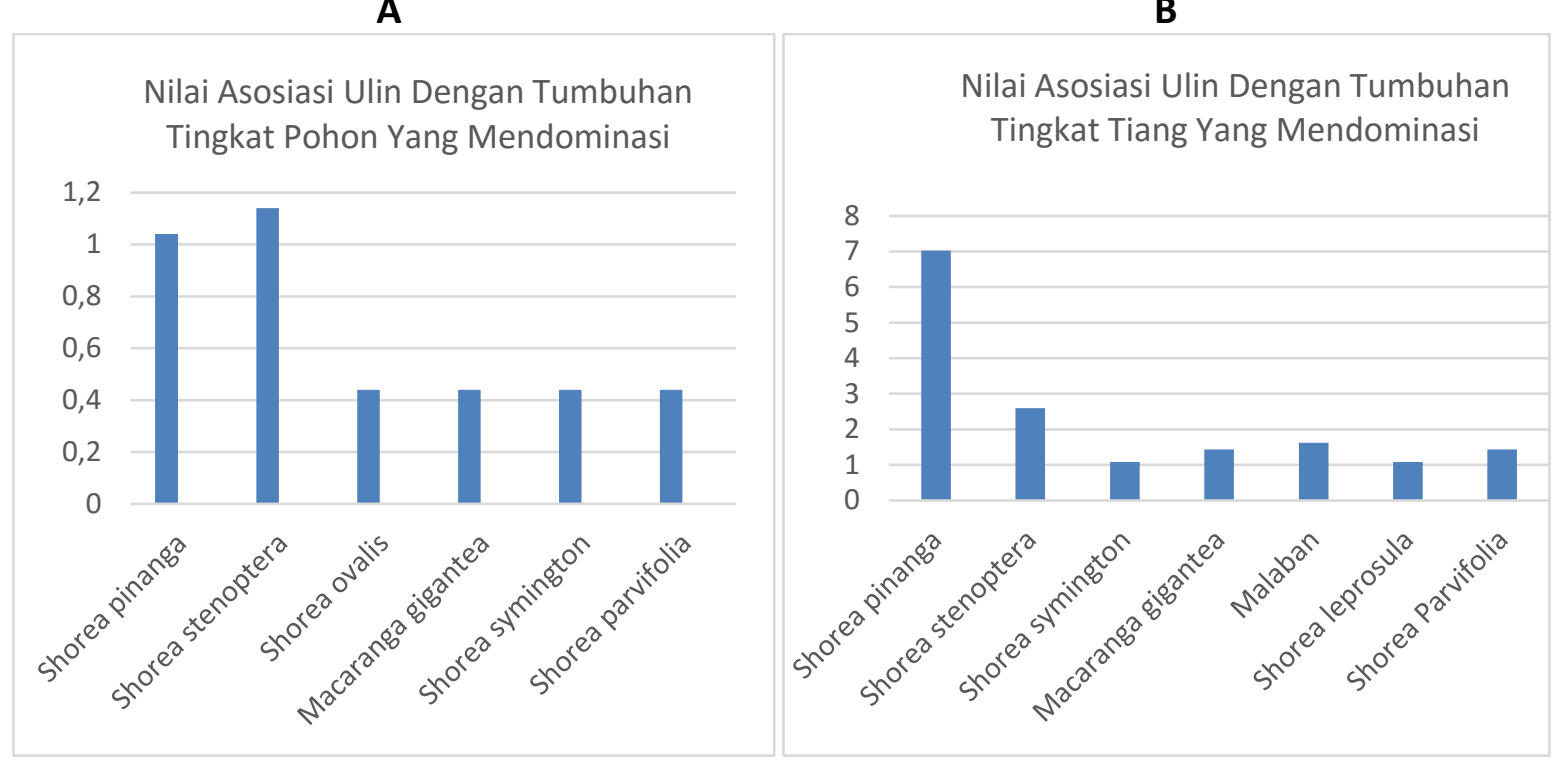

\section{C}

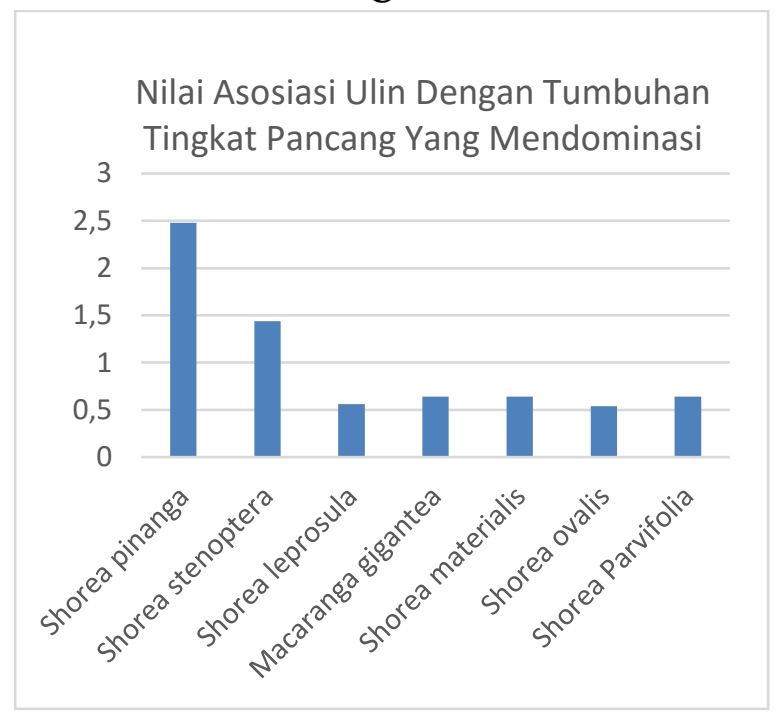

Gambar 5. A. Nilai Asosiasi Ulin Dengan Tumbuhan Tingkat Pohon Yang Mendominasi (Value of Ulin Association with Dominant Plant Tree Level) B. Nilai Asosiasi Ulin Dengan Tumbuhan Tingkat Tiang Yang Mendominasi (Value of Ulin Association with Dominant Plant Level Poles) C. Nilai Asosiasi Ulin Dengan Tumbuhan Tingkat Pancang Yang Mendominasi (The Value of Ulin Associations with Dominant Plant Stakes)

Hasil perhitungan nilai asosiasi menunjukkan bahwa kekuatan asosiasi yang diamati pada tingkat pohon, dan pancang mempunyai tipe asosiasi yang lemah yaitu lebih kecil dari x-tabel $5 \%$ $(3,84)$ kecuali tanaman Shorea pinanga pada tingkat tiang yang memiliki tipe asosiasi kuat dengan $\mathrm{x}$-hitung $(7,02)$ dan menunjukan adanya kombinasi pasangan jenis yang menunjukkan asosiasi tinggi. Untuk mempertegas perhitungan asosiasi, maka ditentukanlah kriteria 
perhitungan indeks asosiasi dengan menggunakan Indeks Jaccard (Ludwig

\section{A}

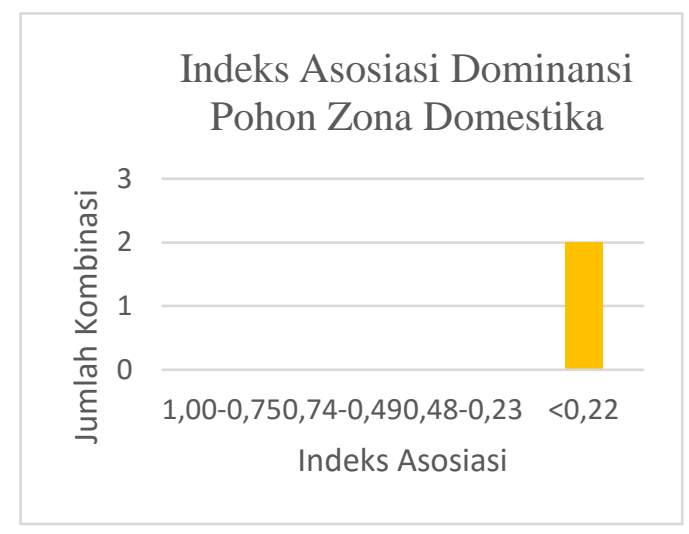

dan Reynolds,1998) dalam Dewantara (2017) seperti pada Gambar berikut.

B

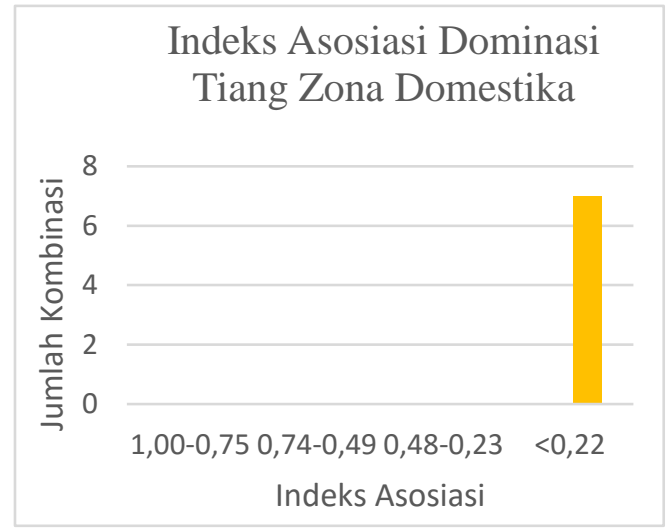

C

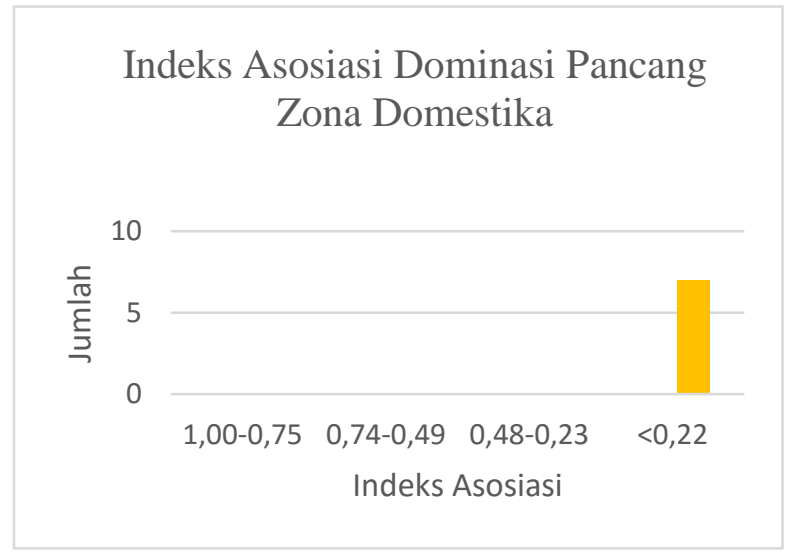

Gambar 6. A. Indeks Asosiasi Dominansi Pohon Zona Domestika (Domestic Zone Tree Dominance Association Index)

B. Indeks Asosiasi Dominasi Tiang Zona Domestika (Domestic Zone Poles Dominance Association Index)

C. Indeks Asosiasi Dominasi Pancang Zona Domestika Domestic Zone Stackes Dominance Association Index)

Hasil indeks asosiasi diatas memperkuat hasil hitung tabel kontigensi. Bahwa tanaman tingkat pohon, pancang, dan tiang di zona domestika Kebun Raya Sambas, menunjukkan tidak adanya toleransi untuk hidup bersama (sangat rendah) dan tidak ada hubungan timbal balik yang saling menguntungkan. Ini dapat kita lihat pada gambar diatas dimana nilai indeks asosiasi seluruh tegakan pada zona domestik adalah $<0,22$ sehingga tingkat toleransinya sangat rendah (Kurniawan et al, 2008).

Menurut Sidiyasa (2011), Ulin biasanya ditemukan menyebar atau berkelompok dengan keadaan kanopi tajuk yang masih tertutup dan berada di lerenglereng hutan. Ulin juga berasosiasi dengan 
tanaman meranti ini dikarenakan kedua tanaman memiliki ketergantungan satu dengan lainnya untuk hidup ditengah perubahan faktor lingkungan yang bersifat ekstrim.

\section{Kesimpulan}

Hasil penelitian Asosiasi Tegakan Ulin Dengan Tumbuhan Dominan di Kebun Raya Sambas, tidak memiliki hubungan timbal balik atau berasosiasi nyata. Namun menunjukkan adanya toleransi untuk hidup bersama dalam satu areal, karena setiap tumbuhan khususnya pada zona domestik membutuhkan naungan mulai dari tingkat semai, pancang, tiang, dan pohon. Meranti Merah merupakan jenis yang paling dominan khususnya Shorea pinanga merupakan spesies yang mendominasi pada zona domestika dengan INP pohon $(59,3760)$, tiang $(58,2746)$, pancang $(53,5636)$, semai $(55,5699)$. Shorea pinanga tingkat tiang memiliki asosiasi kuat dengan tumbuhan Eusideroxylon zwageri $\mathrm{T}$ et $\mathrm{B}(7,02)$, tetapi memiliki indeks

Asosiasi yang sangat rendah $(0,1428)$ sehingga menunjukkan tidak adanya toleransi untuk hidup bersama. Ini dikarenakan kondisi vegetasi yang terlalu padat sehingga tanaman tingkat semai dan pancang sulit untuk tumbuh. Untuk tingkat pohon hanya menyisakan sedikit tegakan saja, ini dikarenakan eksploitasi ulin secara besar-besaran dan pembukaan lahan sehingga tegakan pohon ulin lama kelamaan menurun bahkan terancam populasinya.

$\begin{array}{rrrr}\text { Jadi dapat disimpulkan } & \text { spesies } \\ \text { dominan yang berasosiasi } & \text { dengan } \\ \text { tumbuhan ulin di Kebun Kaya } & \text { Sambas }\end{array}$

adalah Shorea pinanga. Spesies yang mendominasi ini akan dipakai sebagai indikator tentang kehadiran atau keberadaan pohon ulin.

\section{DAFTAR PUSTAKA}

Agung Wahyudi, Sugeng P., Harianto, dan Arief Darmawan. 2014. Keanekaragam Jenis Pohon di Hutan Pendidikan Konservasi Terpadu Tahura Wan Abdul Rachman. Jurnal Sylva Lestari. 2(3): 1-10

Dewantara. 2017. Asosiasi Tengkawang (Shorea spp.) dengan Jenis-Jenis Dominan di Hutan Tembawang Kuala Bahe Kabupaten Landak. DIPA. Fakultas Kehutanan.

Djoko Setyo. 2012. Analisis Vegetasi dan Asosiasi Antara Jenis-Jenis Pohon Utama Penyusun Hutan Tropis Daratan Rendah di Taman Nasional Gunung Rinjani Nusa Tenggara Barat. Jurnal Agrit-Tek. 13(2): 1827.

Hidayat, S. 2003. Persebaran Ulin (Eusideroxylon zwageri T et. B) dan Tumbuhan Asosiasinya di Taman Nasional Kutai, Kalimantan Timur. Jurnal Pusat Konservasi TumbuhanKebun Raya Bogor. 6(1). 39-43.

Indriyanto. 2006. Ekologi Hutan. PT. Bumi Aksara. Jakarta

Kade Sidiyasa, Tri Atmoko, Amir Ma'ruf, Mukhlisi. 2013. Keragaman Morfologi, Ekologi, Pohon Induk, dan Konservasi Ulin (Eusideroxylon zwageri teijsm et binnend) di Kalimantan. Jurnal Penelitian Hutan dan Konservasi Alam 10(3): 241254.

Kilian, U., B. Steiner., H. Krebs., G. Junge., Schmiedeknecht, and R. Hain. 2000. FZB24 Bacillus subtilis - mode of action of a microbial agent 
enhancing plant vitality. Forestry Journal 111(2) : 583-597.

Kurniawan, A., Undaharta, N.K.E. dan Pendit, I.M.R. 2008. Asosiasi Jenisjenis Pohon Dominan di Hutan Dataran Rendah Cagar Alam Tangkoko, Bitung, Sulawesi Utara. Jurnal Biodiverstas. 9(3): 199-203.

Noorhidayah, Sidiyasa, Hajar 2006. Potensi dan Keanekaragaman Tumbuhan Obat Di Hutan Kalimantan dan Upaya Konservasinya. Jurnal Analisis Kebijakan Hutan. 3(2): 95-107.

Riskan. 2004. Natural Regeneration of Eusideroxylon zwageri $\mathrm{T}$ et $\mathrm{B}$. At Mount Meratus Protection Forest, East Kalimantan, Indonesia. Journal of Forestry Research.Journal of forestry. 1(1): 75-81.

Sastrapradja, S., Kartawinata, K., Roemantyo., Soetisna, U., Wiriadinata, H., Riswan,S. 1977. Jenis-jenis Кауи Indonesia. Lembaga Biologi Nasional LIPI. Bogor.

Sidiyasa, K. 2011. Sebaran, Potensi Dan Pengelolaan Ulin Di Indonesia. Prosiding Lokakarya Nasional "Status Konservasi Dan Formulasi Strategi Konservasi Jenis-Jenis Pohon Yang Terancam Punah (Ulin, Eboni Dan Michelia)". Pusat Penelitian Dan Pengembangan Konservasi Dan Rehabilitasi Badan Litbang Kehutanan Bekerjasama Dengan ITTO. Bogor. 